\title{
Power Matters: The Structural Sources of Brazilian Foreign Policy
}

\author{
by Andrés Malamud \\ Institute of Social Sciences, University of Lisbon, Portugal
}

\author{
(AMORIM NETO, Octavio (2011). De Dutra a Lula: a condução \\ e os determinantes da política externa brasileira. Rio de Janeiro: Elsevier)
}

beg your pardon: Octavio wrote a book on what?! For those familiar with previous
publications and the career path of Amorim Neto - and there are many in Brazil as well as abroad - nothing could be more surprising than him writing a book on foreign policy. "Domestic" institutions such as presidents, cabinets and parliaments had always been at the core of his research, and articles in World Politics, Comparative Political Studies, the American Journal of Political Science, and Party Politics have earned him a reputation as a quantitative-oriented, comparative politics scholar. How - and why - could he possibly have transited from a solid terrain that he fully mastered to uncharted territories of another social science he had never previously published? I think two reasons should be called forth to explain this gamble. First, it is not so infrequent for people to come back to their first love, and diplomatic history was among Amorim Neto's earliest and dearest interests - and remained a strong reason for his fondness for politics. Second, and partly as a consequence of the above, he never bought into the idea that comparative politics and international relations were separate disciplines. Rather, as he once wrote that comparative politics was "the politics of the others" (2010), he would most likely subscribe to Javier Solana's dictum that "foreign policy is all about the domestic policy of others", and thus that international relations is the arena of interaction between both comparable and entangled units. In his understanding, all these fields of knowledge fall fully within the sphere of power relations, which is to say that they belong to what political science - and political scientists - study. For such an open mindset, state borders are not stiff enough as to keep knowledge in watertight compartments or, to paraphrase Almond (1988), separate 
tables. So Amorim Neto decided to invest his methodological skills and comparatist training into a new, though related, venture: to find out the determinants of the contemporary foreign policy of his home country.

This book introduces three main innovations to preexisting analyses. They regard methods, time frame and theory. As to methods, this volume is the first systematic attempt to test with empirical data whether it is domestic politics or the international system that have influenced more decisively Brazilian foreign policy. Thus far, discussions had mostly been held between arguments on continuity (accentuating the professionalism of Itamaraty and above-politics strategies) versus change (focusing on leadership and epitomized in the famous Lula's sentence, "never before in the history of this country"). However, both strands of arguments were defended in an impressionistic rather than fact-based fashion and also, more often than not, ideologically biased and normatively oriented. To overcome these pitfalls, Amorim Neto made the careful though risky decision to use a quantitative indicator to measure the orientation of Brazilian foreign policy, and so he resorted to a database that included every non unanimous vote in the General Assembly of the United Nations (Voeten e Merdzanovic 2008) to build the dependent variable, i.e., policy alignment with the United States. It measured the degree of convergence in voting behavior between the two countries over time and across issues, and showed that it decreased abruptly from over $80 \%$ in the 1940 s to around $10 \%$ in the 2000 s.

As the book shows, to consider policy alignment with the United States as a proxy for Brazilian foreign policy at large follows a methodological choice that is shared by virtually all scholars regardless of paradigmatic leaning. Yet, it also brings us to the second innovation: time span. Unlike most of the literature, Amorim Neto does not start his narrative either with Barão de Rio Branco or with the preceding empire. This decision is made on methodological grounds, as there was no UN - and therefore no voting record - prior to 1945. But there is also a substantive reason, which is more visible at the end than at the starting point: as US power recedes, the world becomes more multipolar and South America gains increasing autonomy - or diversifies its dependency, as some would say -, the degree of alignment with the US will cease to be a valid indicator of broader foreign policy goals. Therefore, the analysis carried out in this book was impracticable before 1946 and will become meaningless in the forthcoming years. This acknowledgment is an author's tribute to the importance of context, as it recognizes the limits of pure formal modeling and blind quantitative measurement.

Concerning theory, Amorim Neto claims that his findings vindicate the neo-realist approach, although his focus on foreign policy, his multi-variable research design, and his conclusions put him closer to neo-classical realism than to Waltzian or Mearsheimerian realism. In Gideon Rose's words (1998: 146-7), "neoclassical realists argue that relative 
material power establishes the basic parameters of a country's foreign policy... Yet they point out that there is no immediate or perfect transmission belt linking material capabilities to foreign policy behavior. Foreign policy choices are made by actual political leaders and elites, and so it is their perceptions of relative power that matter, not simply relative quantities of physical resources or forces in being... Furthermore, those leaders and elites do not always have complete freedom to extract and direct national resources as they might wish. Power analysis must therefore also examine the strength and structure of states relative to their societies, because these affect the proportion of national resources that can be allocated to foreign policy". In sum, neoclassical realism holds that the actions of a state in the international system can be explained by systemic, cognitive, and domestic variables affecting the power and freedom of action of the decision-makers in foreign policy. If context matters, then the next question is how - and how much.

Amorim Neto decided to test the impact of nine independent variables on the degree of voting convergence with the US. There were three systemic variables: Brazil's position in the international hierarchy of military and economic power, its degree of asymmetric interdependence, and the preferences of the US. The first variable is tributary to neo-realist theory and was measured by resorting to the Composite Index of National Capability (CINC), a statistical measure of national power that combines six different components representing demographic (total and urban population), economic (iron and steel production and energy consumption), and military (expenditure and personnel) strength. The second variable stems from liberal theories and measures Brazilian exports to the US as a proxy for economic dependence; the third variable regards the intensity with which the US sought to align the Western Hemisphere, and uses a binary variable (incidence of the Cold War) to gauge it.

The six domestic variables include five ideological or ideological-institutional measures as in Latin America the left is mostly associated with anti-Americanism: the president's ideology, the legislative share of his party, the ideological leaning of his cabinet, the legislative strength of left-to-the-center parties, and the presence and weight of military ministers in the cabinet - which is associated to the ideological right. The latter variable captures the nature of the regime (i.e. democratic or not), but it also provides meaningful information about democratic administrations as every branch of the armed forces was entitled to a cabinet minister until the creation of a civilian-ruled Ministry of Defense in 1999. Last, the sixth variable estimates the influence of Itamaraty, the powerful foreign ministry, by calculating diplomatic incrementalism and inertia from one year to the next.

The findings of the ensuing regressions might have been unsettling for a scholar trained to appreciate the significance of government institutions and domestic politics. The paramount discovery of the book is that systemic factors were the main determinant 
behind the formulation of Brazilian foreign policy between the end of World War II and 2008, a period that encompassed eighteen different presidents. Furthermore, these factors were not related to liberal hypotheses (asymmetric interdependence and US preferences as defined by the Cold War) but to the neo-realist hypothesis that focused on the increase in the country's military and economic power. True, some of the domestic factors also showed some significance: the bureaucratic variable (diplomatic inertia generated by the foreign ministry) and, secondarily, the cabinet strength of leftist parties and military ministers, had a complementary effect on policy choices. As the author warns, his tests do not exclude the possibility that systemic-liberal factors and Congress-centered variables had indirect influence over the policy process; yet, structure rather than agency took center stage.

The primacy of high politics (national capabilities) over low politics (interdependence), and of systemic over domestic factors, may have disguised an element that Amorim Neto is eager to bring back to the fore: presidential influence. As he suggests, the political support and personal activism of the chief executive affects the way in which the bureaucratic traditions and ideological alignments interact with each other and with the systemic pressures. Because, as neoclassical realists argue, "systemic pressures and incentives may shape the broad contours and general direction of foreign policy without being strong or precise enough to determine the specific details of state behavior. This means that the influence of systemic factors may often be more apparent from a distance than from up close - for example, in significantly limiting the menu of foreign policy choices considered by a state's leaders at a particular time, rather than in forcing the selection of one particular item on that menu over another" (Rose 1998: 147, my emphasis). Whether consciously or not, Rose's take accurately depicts the author's approach and puts him in company of the likes of Randall Schweller, William Wohlforth and Fareed Zakaria.

The research displayed in this book combines solid statistical analysis with careful consideration of historical context and detail. It hardly leaves loose ends, as it gives balanced consideration to the long term as well as the nitty-gritties of specific situations. For those who are not familiar with the Brazilian academic community, however, this book carries an additional asset that is worth mentioning. In Brazil, unlike the US or Argentina, political science and international relations have developed through parallel tracks. While the former has adopted a nomothetic approach, looking for regularities in the observable phenomena, the latter has prioritized an idiographic approach, aspiring to illuminate the particularities of reality. Hence, Brazilian political science evolved from sociology and became increasingly quantitative and comparative (some would say Americanized), whereas international relations kept a strong connection with history and favored periodization over theorization (more in line with the French tradition). Apart from its substantive 
richness, this book accomplishes the feat of seating both disciplines at the same table and inviting them to dialogue. And it delivers, as the knowledge produced is superior to what it would have been had the two pathways remained separated.

So what comes next? A new avenue of research has been opened up, and there are already young researchers drawing on its methods and contrasting its findings (see Schenoni 2012). Two main challenges, I suggest, lay ahead: the first is to retest whether it is Brazil's increasing national capabilities or rather the capability gap with the United States that determines foreign policy changes, as similar trends have been verified for most other countries (Voeten 2004). The second challenge, linked to the previous one, is to go deeper into combining international relations with comparative politics and to expand this analysis to the region first, and eventually worldwide. How does Brazilian foreign policy determinants compare with Argentina's, Mexico's or, for that matter, India's? Could Brazil be just a regional exception? And if it is not, does it reflect a general pattern or one that is valid just for large powers? The jury is still out, but the scheme for reaching a judgment has been laid out in this book.

Instilled by an eclectic approach, this research is both theory-guided and empirically tested. Amorim Neto engages contrasting arguments and authors, interrogates the facts and leads the reader through a line of reasoning that is respectful but rigorous. In the end, evidence gains primacy over expectations and new causal relations are unearthed. Yet, let justice be done, this book might have had a lesser impact if it were not for the support received from Maria Regina Soares de Lima, who wrote the preface. Given the disciplinary quarrels that pervade the Brazilian scholarly community, the academic reputation and open-mindedness of Maria Regina helped to secure an attentive readership for such a provocative, cross-fertilizing endeavor. The book sets the bar high for future research but, if the effort blossoms, it may also have another lasting effect: to facilitate the rapprochement between comparatists and internationalists and also, perhaps, between temporarily distanced members of the Brazilian diplomatic community. May good scholarship have an influence on the real world, out of the ivory tower.

So yes, Octavio wrote a book on foreign policy. Why wonder? After all, he is a political scientist.

\section{Bibliographical References}

Almond, Gabriel A. 1988. "Separate Tables: Schools and Sects in Political Science”. PS: Political Science and Politics, 21(4): 828-42.

Amorim Neto, Octavio. 2010. “A Política Comparada no Brasil: A Política dos Outros”. In: Renato Lessa, ed., Horizontes das Ciências Sociais no Brasil: Ciência Política. São Paulo: ANPOCS/Editora Barcarolla/ Discurso Editorial/ICH, 321-40. 
Rose, Gideon. 1998. "Neoclassical Realism and Theories of Foreign Policy". World Politics, 51(1), 144-72.

Schenoni, Luis. 2012. "Los determinantes sistémicos de la política externa brasileña en el contexto de América Latina", presented at the IV Uruguayan Congress of Political Science (AUCiP), Montevideo, 14-16 November.

Voeten, Erik. 2004. "Resisting the Lonely Superpower: Responses of States in the United Nations to U.S. Dominance". The Journal of Politics, 66(3), 729-54.

Voeten, Erik and Adis Merdzanovic. 2008. United Nations General Assembly Voting Data, hdl: 1902.1/12379 UNF:3:Hpf6qOkDdzzvXF9m66yLTg==

Revised by Sandra Gomes 